\title{
Students Reasoning Achievement Using Games Performance Assessment Instrument in Physical Education
}

\author{
Norkhalid Salimin \\ Faculty of Sports Science and Coaching \\ Sultan Idris Education University \\ Perak, Malaysia \\ norkhalid@fsskj.upsi.edu.my
}

\author{
Abdul Razak Noruzzaman \\ Physical Education Department \\ Institut Pendidikan Guru Malaysia \\ Perak, Malaysia \\ abdulrazaknoruzzaman@yahoo.com
}

\author{
Mohd Izwan Shahril \\ Faculty of Sports Science and Coaching \\ Sultan Idris Education University \\ Perak, Malaysia \\ izwan.shahril@fsskj.upsi.edu.my
}

\author{
Md Amin Md Taff \\ Faculty of Sports Science and Coaching \\ Sultan Idris Education University \\ Perak, Malaysia \\ md.amin@fsskj.upsi.edu.my
}

\author{
Syed Kamaruzaman Syed Ali \\ Faculty of Education \\ University of Malaya \\ Kuala Lumpur, Malaysia \\ syed@um.edu.my
}

\begin{abstract}
- this study was designed to assess students reasoning achievement based on net and wall category, using Games Performance Assessment Instrument (GPAI) in Physical Education. The design used in this study was Quasi experimental design which consist of 240 form II students in the district of Hilir Perak, Perak. The treatment group is allowed to undergo teaching and learning programs based on net and wall TGfU mode, while; the control group undergo Technical Model. The students reasoning achievement were determined using percentage statistics such as mean and standard deviation; while the research hypothesis were answered using ANCOVA analysis. The pre-test result of the treatment group showed overall $(\mathrm{M}=2.04 ; \mathrm{SD}=\mathbf{0 . 4 8})$ compared to the control group which showed overall $(M=2.00 ; \mathrm{SD}=0.38)$; meanwhile the treatment group showed overall $(M=3.84 ; S D=0.77)$ in the post-test which is higher when compared the control group which showed overall $(M=3.19 ; \mathrm{SD}=0.96)$ in the post-test. The reasoning achievement of the students at excellent level showed that the treatment group $(n=57 ; 40.70 \%)$ is higher than control group $(n=27 ; 19.30 \%)$.From these results, it was evidenced that there was a significant difference between the study group that was adjusted with the pre-test and post-test $F$ $(1,276)=0.93, P=0.336$. The implication of this study suggested that GPAI can be used as an alternative instrument for determining the level of learning domain based on reasoning to achieve higher order thinking skills.
\end{abstract}

Keywords-games performance, assessment, physical education

\section{INTRODUCTION}

Physical education syllabus consists of three outlined key elements which include fitness, skills and sports [1]. One of the most important components of physical education is game, which comprises of various types of field and court games including football, netball, table tennis, handball, badminton, volleyball, softball, hockey, tennis, sepaktakraw, basketball, cricket and rugby. The implementation of the teaching and learning in physical education is the introduction and exposure to the basic skills of the games.
Through teaching and learning in Physical Education (PE), students are taught to master the basic skills of games which enable them to execute these skills during training, competitions or recreational activities [2]. For a student to have technical skills in tandem with cognitive ability during games, skill is required [3]. Elements of reasoning that require mastering during games includes understanding the concepts of the game, tactics, strategies, decision making and implementation of skills. Therefore, reasoning skills need to be applied in the teaching and learning process to improve student's performances level, and also student's intellectual excellence through games [4].

Reasoning in game requires an individual to be able to process the information received, analyze, elaborate, and make decisions in tactical aspects and game strategies. For students to make decisions in game situations, they should not only master the skills from technical aspects, but they are also required to be able to reason about the game tactics and strategies [5]. Students also need to be wise and calculative in game situations such as; the attacking position, defending position, and planning strategies so as to earn points. To execute skills, reasoning competency is required so as to be able to coordinate the accuracy of action with the decisions made to achieve goal of the games [6].

Generally, teachers in Malaysia teach games topics in PE based on the Technical Model of Mosston and Ashworth's Teaching Style [7, 8, 9, 10]. Teachers conduct teaching sessions by introducing basic skills through advanced activities and training; after which the students are allowed to play in small games. Teaching based on the Technical Model of Mosston and Ashworth's emphasizes more on the technique or (and) skill of the game. Demonstration and imitation are emphasized in the Technical Model of teaching, in which the teacher immediately corrects the students if they are unable to execute the technical skills correctly [11]. 
Technical Model of teaching allows students to master the basic skills and techniques of a game well [12]. However, according to some researchers [13, 14, 15], it was found that students only mastered the technique of skills, but failed to perform well in the strategy and tactical aspects in game situati ons. Their finding shows that students' behavior is more geared towards game technique and skills, compared to strategy or tactics execution to earn points or win during games. Due to their findings, it is also suggested that teachers should implement teaching methods that are more mind-challenging so that students are able to apply strategy planning, tactics, and decisions making to enable them play wisely.

Strategy mastery, tactics, and ability to make suitable decisions such as the delivering direction, best technique to earn points, and the best position to receive the ball can help players perform effectively in games $[13,16,17]$. Technical Model method of teaching does not emphasize the reasoning aspect of games which involves decision making and problem solving [18]. The aspect of Technical Model that involves reasoning can be seen through absorptive skills to produce strengths and suitability of limbs in preparation with the objects to be received or delivered [19]. However, reasoning aspect of games should be extended to decisionmaking on game concepts, tactics, strategies and game performance [20]. Emphasizing on the technical skill aspect of a game alone will hinder the understanding, skill and game mastery in overall.

Introducing a new teaching model of games with tactical approach known as Teaching Games for Understanding (TGfU) enables students to learn games based on cognitive skills, through problem solving activities and decisionmaking process [21]. Game is one of the tools that can be used for the development of students' reasoning skills through problem solving activities such as; decision making, planning strategies, and tactics. TGfU model of teaching uses tactical approach which can motivate students to think creatively, make wise decisions on tactical selection, maintain good teamwork, and also master sports skills [22].

TGfU model is a tactical and strategy approach to improve thinking, decision making and problem solving before using skills in games. The approach used should stimulate the student's mind about the game's understanding in overall. TGfU model of teaching also lay emphasizes on concepts including thinking, teaching, training and playing with fun. TGfU model was introduced when it was discovered that other models of games teaching did not attract the students [21]. Therefore, a study was conducted as a problem solving approach which involves the technique of playing while studying. As a result of this study, students were exposed to learning techniques in a playing atmosphere where they are free to enjoy and able to explore the use of model under monitoring by their teachers. TGfU model of approach allows students to improve and maximize their reasoning ability, because it is a model that emphasizes more on the concept of reasoning.

The important aspect of the model lies in the adaptation of the game which requires the students to make decisions in games [23]. Without doubt, skills can increase students understanding towards a game comprehensively, but they are also required to formulate and make use of their own ideas through reasoning to solve game problems. TGfU model helps to enhance cognitive skills through demonstrative learning in games [24]. Understanding game situations are not just about execution of skills, but doing what needs to be done as the best action in the game [25]. Decision making during games reveals that there is a close connection between game teaching and reasoning skills, which is the process of making appropriate judgments in problem solving.

TGfU Model and Technical Model are two different approaches, and they are used in achieving teaching objectives for the topic of games in PE. Educational development in Malaysia that demands high-level thinking skills, especially reasoning skills has changed the paradigm of teachers towards the concepts, approaches and teaching methods to be delivered. For the success of games, reasoning skills which includes tactics, strategy, decision making, and skills implementation aspects is highly important $[26,27]$. Therefore, the need for studies that specifically examine the effect of the teaching method used by the teachers on the level of performance in games based on reasoning should be implemented. Teachers of Physical Education need to be able to manage teaching and learning process effectively, to induce understanding of reasoning ability through cognitive and behavioral developments that help students master games more effectively.

The objective of this study was to assess students reasoning level achievement through GPAI based on net and wall of the category games, and the effectiveness between TGfU Model and Technical Model in Physical Education.

\section{RESEARCH OBJECTIVES}

The specific objectives of this study are to:

i. assess the students' reasoning level achievement through GPAI based on net and wall of the category games.

ii. evaluate the effectiveness between TGfU Model and Technical Model in Physical Education.

\section{RESEARCH Methodology}

This study was designed to assess students reasoning achievement based on net and wall category using GPAI and the effectiveness between TGfU Model and Technical Model in Physical Education. The experimental design used in this study was Quasi experimental design, which involved 280 Form II students in Hilir Perak, Perak. The subjects used in this study were divided into the treatment group and the control group. The treatment group undergoes net and the wall category teaching and learning program based on TGfU model, while the control group undergoes badminton games Technical Model.

The subjects of each group were allowed to undergo teaching and learning sessions six times according to the lesson plans and research instrument used. GPAI (reliability: 
Decision making $=0.86$, Adjust $=0.98$, Skill execution $=$ $0.86)$. The percentage statistics such as mean and standard deviation are used to determine the students reasoning achievement, while ANCOVA analysis is used to identify the effectiveness between TGfU Model and Technical Model in Physical Education.

\section{RESULT AND DISSUSSION}

TABLE I. STUDENTS REASONING ACHIEVEMENT By GENDER

\begin{tabular}{llllllllll}
\hline Location & Gender & \multicolumn{3}{c}{ Treatment group } & \multicolumn{3}{c}{ Control group } \\
& & Pre-test & \multicolumn{3}{c}{ Post-test } & Pre-teat & \multicolumn{2}{c}{ Post-test } \\
& & Mean & SD & Mean & SD & Mean & SD & Mean & SD \\
\hline Urban & Male & 2.04 & 0.45 & 3.93 & 0.59 & 2.04 & 0.34 & 3.28 & 0.76 \\
& Female & 2.04 & 0.48 & 3.83 & 0.72 & 2.00 & 0.36 & 3.46 & 0.98 \\
& Total & 2.04 & 0.46 & 3.88 & 0.66 & 2.02 & 0.35 & 3.37 & 0.88 \\
Rural & Male & 2.08 & 0.51 & 3.74 & 0.89 & 1.90 & 0.40 & 3.13 & 1.04 \\
& Female & 2.00 & 0.50 & 3.84 & 0.86 & 2.06 & 0.42 & 2.90 & 0.97 \\
& Total & 2.04 & 0.50 & 3.79 & 0.87 & 1.99 & 0.41 & 3.01 & 1.00 \\
Overall & & 2.04 & 0.48 & 3.84 & 0.77 & 2.00 & 0.38 & 3.19 & 0.96 \\
\hline
\end{tabular}

Table 1 shows the students reasoning achievement by gender based on net and wall category games of treatment group and control group. The pre-test result of treatment group showed overall $(\mathrm{M}=2.04 ; \mathrm{SD}=0.48)$ compared to the control group $(\mathrm{M}=2.00 ; \mathrm{SD}=0.38)$. After six times of teaching and learning sessions, treatment group $(\mathrm{M}=3.84$; $\mathrm{SD}=0.77)$ showed higher in post-test compared to control group $(\mathrm{M}=3.19$; $\mathrm{SD}=0.96)$. The difference of mean score in pre-test and post-test for the treatment group was 1.80 while that of control group was 1.19.

TABLE II. Grade Students Reasoning Achievement

\begin{tabular}{lll}
\hline Grade & \multicolumn{1}{c}{ Treatment group } & Control group \\
\hline Excellent & $40.70(\mathrm{n}=57)$ & $19.30(\mathrm{n}-27)$ \\
Good & $42.90(\mathrm{n}=60)$ & $30.70(\mathrm{n}=43)$ \\
Pass & $10.00(\mathrm{n}=14)$ & $31.40(\mathrm{n}=44)$ \\
Moderate & $5.00(\mathrm{n}=7)$ & $14.30(\mathrm{n}=20)$ \\
Weak & $1.40(\mathrm{n}=2)$ & $4.30(\mathrm{n}=6)$ \\
\hline
\end{tabular}

Table 2 shows Grade Students Reasoning Achievement distribution.

According to the finding, treatment group student achieved higher at excellent level $(\mathrm{n}=57 ; 40.70 \%)$ when compared to the control group $(\mathrm{n}=27 ; 19.30 \%)$.

TABLE III. MEAN REASONING ACHIEVEMENT By ITEM

\begin{tabular}{lcc}
\hline Test Item & Mean Treatment Group & Mean Control Group \\
\hline Decision Making & 3.66 & 3.02 \\
Adjust & 3.88 & 3.07 \\
Skill Execution & 3.97 & 3.46 \\
Overall & 3.84 & 3.19 \\
\hline
\end{tabular}

Table 3 shows mean achievement details by item for treatment group and control group.

The treatment group achievement for all the three test items which are: Decision making, adjust and skill execution are higher than that of the control group. In overall, the treatment group $(\mathrm{M}=3.84)$ was found to be higher than the control group $(\mathrm{M}=2.19)$.
TABLE IV. ANALYSIS OF COVARIANCE SUMMARY

\begin{tabular}{llllll}
\hline Source & $\begin{array}{l}\text { Sum of } \\
\text { Squares }\end{array}$ & df & $\begin{array}{l}\text { Mean } \\
\text { Square }\end{array}$ & F & $\begin{array}{l}\text { Partial Eta } \\
\text { Squared }\end{array}$ \\
\hline Corrected Model & 34.5956 & 2 & 17.297 & $23.459^{*}$ & .145 \\
Intercept & 100.294 & 1 & 100.294 & $136.020^{*}$ & .329 \\
Pretest Score & 5.452 & 1 & 5.452 & 7.394 & .026 \\
Treatment & 27.988 & 1 & 27.988 & $37.957^{*}$ & .121 \\
Treatment by Pretest Score & 204.246 & 277 & .737 & & \\
Error & 3694.556 & 280 & & & \\
Total & 238.841 & 279 & & & \\
${ }^{* 8} \mathrm{p}<0.05$ & $\mathrm{R}^{2}=0.145$ (Adjusted $\left.\mathrm{R}^{2}=0.139\right)$ & & \\
\end{tabular}

According to table 4, ANCOVA analysis was used to identify the effectiveness between TGfU Model and Technical Model in Physical Education. The result showed significant difference between the study group that was adjusted with the pre-test and post-test in the control group and the treatment group; while the pre-test showed no significant different with the post-test, $\mathrm{F}(1,280)=7.394, \mathrm{P}$ $=0.070$.

GPAI instrument was implemented to assess the game reasoning behaviors including the ability to make decisions, the ability to adjust, and the aspect involving skill execution. The treatment group achievement was found to be higher than that of the control group. This shows that this finding is in line with previous studies $[16,28,29]$ which showed that the reasoning achievement performance of student group who used TGfU Model is higher than that of student group who used Technical Model. 
This finding also shows that urban students reasoning achievement for treatment group is higher than that of rural students. This shows that the urban students mastered the reasoning skills better in net and wall games compared to the rural students. The result of this study was in line with previous studies $[16,22,28,29]$ which showed that the reasoning achievement of TGfU group was higher than that of Technical groups. Urban students are more exposed to reasoning skills as the implementation of reasoning concept occurs in the teaching of all subjects in schools [30].

Furthermore, this finding also showed that the treatment group had successfully developed the reasoning skills gained during the teaching session using TGfU Model, for a better game. They were also able to modify their game skills according to the needs and situations. The treatment group have received intervention through TGfU Model conducted during performance evaluation in teaching and learning sessions. GPAI assessment aims to assess the students' ability to reason in depth. GPAI assessment in PE is significant because it involves psychomotor domain which is based on reasoning, and it also help to enhance the mastery of game reasoning behavior at higher level that is implemented during training session.

GPAI instrument enables the teachers to evaluate the progress of students achievement individually during training and game sessions. Indirectly, teachers will be more focused to give attention and instruction to each individual. Also, students will be able to master more complex and highly skilled tactics in game mastery, and an actual game behavior assessment method based on reasoning [27].

\section{CONCLUSION}

Students reasoning achievement based on net category games and walls in PE are efforts to produce scientifically based thinking, and also to increase the effectiveness of teaching and learning in schools. The development of ideas regarding the generation of teaching and learning model is believe to be a guide among educators to further strengthen their teaching effectiveness.

This study concludes that the use of the TGfU Model can enhance students' scope holistically and comprehensively on reasoning achievement. GPAI instrument provides students with more effective knowledge and skills, and it is hoped that GPAI can guide the development of knowledge in PE as a whole.

The implication of this study suggests that; GPAI as an alternative instrument can be used to determine the level of learning domain based on reasoning towards the achievement of higher thinking level skills.

\section{REFERENCES}

[1] Curriculum Development Center, Description of primary and secondary syllabus. Kuala Lumpur: Ministry of Education Malaysia. 1999.

[2] O. K. Swee \& W. E. Hoe, Modul pengajaran permainan badminton. Selangor: Oxford Fajar Sdn Bhd. 2006

[3] G. Olosova, L. Zapletalova, "Effects of a teaching games for understanding approach and a technical approach to teaching basketball on declarative and procedural knowledge," Journal of Sport, Physical Activity and Health, 2014, 15, 192-195.
[4] A. Chatzipanteli, N. Digelidis, \& R. Dean, "Promoting students' metacognitive behavior in physical education through TGfU," American Journal of Educational Science, 2015, 1(2), 28-36.

[5] P. K. Miller, L. Rowe, C. Cronin, \& T. M. Bampouras, "Heuristic reasoning and the observer's view: The influence of exampleavailability on ad-hoc frequency judgments in sport," Journal of Applied Sport Psychology, 2012, 24, 290-302.

[6] L. Lilie, D. Aleksic, \& R. Stefanovic, "The specifics of cognitive abilities of football players in relation to the rank of competition," Research in Kinesiology Federation of Sports Pedagogy, 2012, 2, 147 154.

[7] T. B. Tong, Pendidikan jasmani dan pendidikan kesihatan. Selangor: Pearson Education Malaysia Sdn Bhd. 2001.

[8] E. A. Meng, Pedagogi III, Edisi Ke-2. Selangor: Penerbit Fajar Sdn Bhd. 2002.

[9] S. Z. Alauddin, S. K. Geok, R. O. Dev \& M. F. Hassan, "Penilaian masa pengajaran pendidikan jasmani selama 40 minit di sekolah menengah. Kajian Sukan di Malaysia Jilid 2. Universiti Putra Malaysia. 2014.

[10] M. Mosston, \& S. Ashworth, Teaching physical education(4 ${ }^{\text {th }}$ ed.). New York: Macmillan. 1994.

[11] S. H. Amy, W. Lijuan, \& J. Collins, "Perception of Hong Kong physical education teacher on teaching games for understanding: Implications for continuing profesional development," Educational Research Journal, 2014, 29, 92-110.

[12] S. Wright, M. McNeill, J. Fry, \& J. Wang, "Teaching teachers to play and teach games. Physical Education and Sport Pedagogy," 2005. 10(1), 61-82.

[13] J. Y. Chow, \& C. Tan, "Enhancing game play in PE and sport: A holistic approach," In perspectives on physical education and sports science in Singapore: An eye on the youth olympic games $2010 \mathrm{ed}$. N. Aplin, 106-17. 2009.

[14] R. Psotta, \& A. Martin, "Changes in decision making skill and skill execution in soccer performance: The intervention study," Acta Univ. Palacki. Olomic, Gymn, 41(2), 7-15. 2011.

[15] S. Gray, \& J. Sproule, Developing pupils performance in team invasion games. Physical Education and Sport Pedagogy, 2011, 16 (1), 15-32.

[16] G. V. Broek, F. Boen, M, Claessens, J. Feys, \& T. Ceux, "Comparison of three instructional approaches to enhance tactical knowledge in volleyball among university students," Journal of Teaching in Physical Education, 2011, 30, 375-392.

[17] S. Stolz, \& S. Pill, Teaching games and sport for understanding: Exploring and reconsidering its relevance in physical education. European Physical Education Review, 20(1), 36-71. 2014.

[18] T. J. Hepler, \& M. A. Chase, "Relationship between decision-making, task self-efficacy, and the performance of a sport skil," Journal of Sports Sciences, 2008, 26, 603-610.

[19] A. P. Turner, \& T. J. Martinek. "An investigation into teaching games for understanding: effects on skill, knowledge, and game play," Research Quarterly for Exercise and Sport, 70(3), 286-296. 1999.

[20] M. Blomquist, T. Vanttinen, \& P. Luhtanen, "Assessment of secondary school students' decision-making and game-play ability in soccer," Physical Education and Sport Pedagogy, 10(2), 107-119. 2005.

[21] D. Bunker, \& R. Thorpe, "A model for the teaching of games in the secondary school. Bulletin of Physical Education,” 10, 9-16. 1982.

[22] N. Sanmuga, "The Effect of Teaching Games of Understanding as a Coaching Instruction Had on Adjust, Cover and Heart Rate among Malaysian and Indian Junior Hockey Players," Sports, 5(2), 1-14. 2017.

[23] L. L. Griffin, \& J. I. Butler, Teaching games for understanding-theory, research and practice. United State: Human Kinetics. 2005.

[24] P. Dodds, L. L Griffin, \& J. L. Placek, "Chapter 2 A selected review of the literature on development of learners' domain-specific knowledge," Journal of the teaching in Physical Education (Monograph), 20, 301-313. 2001.

[25] J. Butler, \& L. Griffin, More teaching games for understanding: Moving globally. Champaign, Illinois: Human Kinetics. 
[26] J. L. Lund, \& M. F. Kirk, Performance-based assessment for middle and high school physical education. United State: Human Kinetic. 2002.

[27] A. S. Goodie, P. Doshi, \& D. L. Young, "Levels of theory-of-mind reasoning in competitive games," Journal of Behavioral Decision Making, J. Behav. Dec. Making, 2012, 25, 95-108.

[28] B. N. Susan, "Effects of the tactical games approach on student engagement in a sport education badminton season," Vahperd. 2010. 19-22.

[29] D. Gutie'rrez, J. Fisette, L. M. G. Lopez, \& O. Contreras, "Assessment of secondary school students' game performance related to tactical contexts," Journal of Human Kinetics, 2014, 42, 223-234.

[30] H. Maidinsah, Kesan kaedah pengajaran meta kognisi - inkuiri terhadap prestasi dalam matematik dan penaakulan saintifik di kalangan pelajar diploma. Tesis $\mathrm{PhD}$ yang tidak diterbitkan. Universiti Sains Malaysia. 2004. 